\title{
Fuels for Fuel Cells: Requirements and Fuel Processing
}

\author{
Jan Van herle ${ }^{a \star}$, Alexander Schuler ${ }^{b}$, Lukas Dammann ${ }^{c}$, Marcello Boscod, Thanh-Binh Truong ${ }^{d}$, \\ Erich De Boni ${ }^{d}$, Faegheh Hajbolourie, ${ }^{\text {, Frédéric Vogel }}{ }^{\mathrm{d}}$, and Günther G. Scherer ${ }^{\mathrm{e}}$
}

\begin{abstract}
Polymer electrolyte and solid oxide are the two fuel cell types (PEFC, SOFC) under development in Switzerland. The very distinct operating temperatures of $80^{\circ} \mathrm{C}$ (PEFC) and 800-950 ${ }^{\circ} \mathrm{C}$ (SOFC) impose fundamentally different requirements upon the nature of the fuel; normally purified $\mathrm{H}_{2}$ for the former ( $\mathrm{CO}$ trace) and usually synthesis gas for the latter $\left(\mathrm{H}_{2}, \mathrm{CO}\right.$ as main constituents). Apart from stored hydrogen, the most relevant fuels are primary hydrocarbons (natural gas, biogas, liquids,...), that then need processing (chemical conversion, cleaning) up to a level compatible with the fuel cell catalysts. These processes are briefly reviewed. Fuel compositions with an emphasis on impurities are given. Two application examples from Swiss R\&D are presented: gasoline conversion to high purity $\mathrm{H}_{2}$ for PEFC and contaminated biogas processing for SOFC.
\end{abstract}

Keywords: Biogas · Fuel impurities · Fuel processing · Partial oxidation · Reforming

\section{Introduction}

Polymer electrolyte and solid oxide are the two fuel cell types (PEFC, SOFC) being developed in Switzerland, the first essentially for mobile and the second essentially for stationary applications. The first has to carry or locally generate its fuel (mostly pure $\mathrm{H}_{2}$ ) from a stock whereas the second can be supplied from either a stored or a distributed fuel (often natural gas).

\footnotetext{
Correspondence: Dr. J. Van herle ${ }^{a}$

Tel.: +41216933510

Fax: +41216933502

E-Mail: jan.vanherle@epfl.ch

aLaboratory of Industrial Energy Systems (LENI)

Bât. ME A2

Faculty of Engineering (STI)

Federal Institute of Technology (EPFL)

$\mathrm{CH}-1015$ Lausanne

bSulzer HEXIS Ltd

Hegifeldstr. 30

PO Box 65,

$\mathrm{CH}-8404$ Winterthur

'Zürcher Hochschule Winterthur (ZHW)

Technikumsstr.

$\mathrm{CH}-8404$ Winterthur

dPaul Scherrer Institut

Laboratory for Energy and Materials Cycles

$\mathrm{CH}-5232$ Villigen

epaul Scherrer Institut

Laboratory for Electrochemistry

$\mathrm{CH}-5232$ Villigen
}

The widely distinct operating temperature regimes of $60-100{ }^{\circ} \mathrm{C}$ for PEFC and $750-950{ }^{\circ} \mathrm{C}$ for SOFC impose fundamentally different requirements upon the nature of the fuel. PEFC use Pt-based anodes as the one sufficiently active catalyst material capable of oxidising, at temperatures close to ambient, the most reactive fuel (hydrogen). SOFC, since oxidation kinetics are strongly accelerated at its high working temperatures, use noble-metal free anodes, usually nickel-based, to readily convert not only $\mathrm{H}_{2}$ but also $\mathrm{CO}$ (carbon monoxide) fuel. At low temperature on the other hand, $\mathrm{CO}$ strongly adsorbs on $\mathrm{Pt}$, effectively blocking the catalyst sites, to the extent that no more than $50 \mathrm{ppm} \mathrm{CO}$ in a PEFC fuel stream can be tolerated.

$\mathrm{H}_{2}$ fuel for PEFC is therefore ideally supplied from water electrolysis using renewable sources (hydro, wind, solar), the overall efficiency and emission balance being penalized if the electricity for electrolysis is fossil-derived. The bulk of $\mathrm{H}_{2}$, however, is produced from natural gas (mainly) or other primary hydrocarbon sources by more economic high-temperature processes like steam reforming (SR, reaction with steam) and partial oxidation (POX, reaction with air or $\mathrm{O}_{2}$ ) on specific catalysts. $\mathrm{CO}$ is always formed as byproduct in these reactions $\left(\mathrm{H}_{2}+\mathrm{CO}\right.$ synthesis gas or syngas $)$ and therefore, unlike for SOFC, has to be eliminated to feed PEFC. This is usually accomplished by low temperature (200-400 ${ }^{\circ} \mathrm{C}$ ) water gas shift reactions followed by a preferential oxidation step (PROX).
The processes will be briefly described. In a high-temperature system (SOFC), they are thermally integrated with the hot fuel cell, thereby raising the total efficiency, compared to a low-temperature system (PEFC) where 'hot' processing is external to the cold fuel cell. In principle, hydrocarbon conversion to synthesis gas can be located on the SOFC Ni-anode catalyst (in situ reforming). This may lead to important thermal gradients between the endothermal reforming and exothermal fuel oxidation reaction zones. Ultimately, hydrocarbon fuel is directly converted to the $\mathrm{H}_{2} \mathrm{O}+\mathrm{CO}_{2}$ products (direct oxidation), leading to the theoretically highest efficiency but requiring other catalysts than $\mathrm{Ni}$ (f.ex. conducting oxides [1]). Ni alone immediately deposits solid carbon and deactivates. The PEFC variant of direct hydrocarbon feeding exists as DMFC (direct methanol fuel cell) with methanol being directly oxidised at Pt anodes.

In principle, then, any fuel can be supplied to a fuel cell - even coal - provided that it is either directly compatible or else sufficiently processed (gasification, conversion to syngas) and purified (CO cleanup, impurities removal), depending on the fuel cell type, working temperature, and catalysts used. Of particular interest are also biofuels (wood, biogas). With these the characteristic impurities are of special concern for catalyst poisoning. Detailed compositions and their effects will be specified. In the final section of the article, two challenging examples of fuel processing ap- 
proaches and projects in the Swiss fuel cell $\mathrm{R} \& \mathrm{D}$ scene are presented: (i) pure $\mathrm{H}_{2}$ production by mixed reforming from a liquid distributed source (gasoline) for mobile application (PEFC cars), and (ii) partial oxidation of real (i.e. contaminated) biogas, an important niche application for the stationary SOFC market.

\section{Fuels}

Fuels applicable to fuel cells are not directly classified as 'primary $v s$. derived', 'hydrocarbon vs. hydrogen', or 'fossil vs. renewable', these classifications being partly redundant and not sufficiently distinctive. Ideally, a primary fuel is converted directly to products by the fuel cell anode catalyst. The advantage of a direct methanol feed (DMFC), for example, is the direct use of a high energy density, liquid fuel in mobile applications. This avoids on-board storage or generation of pure $\mathrm{H}_{2}$ on the device and thereby complex fuel conversion and purification. This is not at present the standard situation. For the SOFC case, hydrocarbons pyrolyse on nickel to solid carbon. For the PEFC case, methanol is slower to oxidize than $\mathrm{H}_{2}$, leading to lower power density than with $\mathrm{H}_{2}$ fuel (necessitating higher Pt loads). Furthermore, $\mathrm{MeOH}$ leakage occurs through the polymer membrane electrolyte. Fuel crosses over by electroosmosis: $\mathrm{H}^{+}$is solvatised by $\mathrm{CH}_{3} \mathrm{OH}$ dragging it to the cathode, thereby wasting fuel (efficiency drop) and lowering the cathode potential by establishment of a mixed potential between $\mathrm{O}_{2}$ reduction and $\mathrm{MeOH}$ oxidation.

Real fuels are not pure chemicals but a mixture of majority, minority, and impurity compounds. As a demonstrative example, consider the biogas compositions in Table 1.

Liquid hydrocarbons like gasoline, kerosene, or diesel are highly complex mixtures of alkanes, alkenes, and aromatics in the ranges $\mathrm{C}_{5}-\mathrm{C}_{10}, \mathrm{C}_{10}-\mathrm{C}_{13}$ and $\mathrm{C}_{13}-\mathrm{C}_{16}$, respectively.

A real fuel requires two general treatments to render it compatible for a fuel cell:

a) Chemical conversion: high-temperature reactions to transform the majority constituent(s) of the fuel into synthesis gas, the mixture of $\mathrm{H}_{2}$ and $\mathrm{CO}$ (main), $\mathrm{H}_{2} \mathrm{O}$, $\mathrm{CO}_{2}$ and unreacted fuel; these reactions involve steam $\left(\mathrm{H}_{2} \mathrm{O}\right), \mathrm{CO}_{2}$ and/or oxygen (air or pure) and are performed over specific catalysts.

b) Cleaning: the removal of impurities or trace compounds that may affect (poison) the fuel cell anode catalyst and/or fuel conversion catalyst.

The various fuel processing steps are described below, starting from natural gas as primary fuel example, and going from high- to low-temperature processing steps.
Table 1. Composition range of diverse biogases [2]

\begin{tabular}{|c|c|c|c|}
\hline vol\% & Farm biogas & Wastewater biogas & MSW/ISW biogas ${ }^{a}$ \\
\hline $\mathrm{CH}_{4}$ & $59.11 \pm 3.04$ & $62.62 \pm 1.21$ & $51.16 \pm 4.04$ \\
\hline $\mathrm{CO}_{2}$ & $30.94 \pm 2.28$ & $34.83 \pm 1.28$ & $43.46 \pm 5.97$ \\
\hline $\mathrm{O}_{2}$ & $1.86 \pm 0.6$ & $0.19 \pm 0.06$ & $0.5 \pm 0.4$ \\
\hline $\mathrm{N}_{2}$ & $6.91 \pm 2.22$ & $0.73 \pm 0.22$ & $1.86 \pm 1.66$ \\
\hline $\mathrm{H}_{2} \mathrm{O}$ & $1.14 \pm 1.05$ & $1.81 \pm 0.69$ & $2.95 \pm 2.76$ \\
\hline $\mathrm{H}_{2}$ & $0.001-0.024$ & 0.002 & 0.04 \\
\hline $\mathrm{H}_{2} \mathrm{~S} \mathrm{ppmv}$ & 50 & $2 \pm 1$ & $350 \pm 5$ \\
\hline $\mathrm{CH}_{3} \mathrm{SH}$ ppmv & 0.3 & $1.8 \pm 0.2$ & $2 \pm 0.2$ \\
\hline$\left(\mathrm{CH}_{3}\right)_{2} \mathrm{~S} \mathrm{ppmv}$ & 0.3 & $1.8 \pm 0.2$ & 0.3 \\
\hline $\mathrm{S}$ total $\mathrm{mg} / \mathrm{m}^{3}$ & $5 \pm 3 / 10 \pm 3^{b}$ & $5 \pm 3$ & $390 \pm 40$ \\
\hline $\mathrm{Cl}$ tot $\mathrm{mg} / \mathrm{m}^{3}$ & $17 \pm 3 / 37 \pm 3^{b}$ & $15 \pm 3 / 24 \pm 3^{b}$ & $25 \pm 3$ \\
\hline $\mathrm{Cl}$ org. $\mathrm{mg} / \mathrm{m}^{3}$ & 0.5 & 0.5 & 0.5 \\
\hline $\mathrm{F}$ tot $\mathrm{mg} / \mathrm{m}^{3}$ & $4 \pm 2.5$ & $4 \pm 2.5 / 6 \pm 2.5^{b}$ & $5 \pm 2.5$ \\
\hline $\mathrm{F}$ org. $\mathrm{mg} / \mathrm{m}^{3}$ & 0.5 & 0.5 & 0.5 \\
\hline Si org. mg/m³ & 30.9 & $13 / 38.8^{b}$ & 6.4 \\
\hline Others ( $1 \mathrm{ppm}$ trace) & $\begin{array}{l}\text { dimethylacetamide, } \\
\text { toluene, CFC, phenol }\end{array}$ & $\begin{array}{l}\mathrm{C}_{10}-\mathrm{C}_{12} \text { alkanes, } \\
\text { dimethylacetamide, } \\
\mathrm{C}_{10} \text { terpene, toluene }\end{array}$ & $\begin{array}{l}\text { ketones }\left(C_{3}-C_{10}\right) \text {, } \\
\text { terpenes }\end{array}$ \\
\hline
\end{tabular}

aMunicipal/industrial solid wastes

${ }^{\mathrm{b}}$ Two different concentration ranges measured on two distinct biogas sites

\section{Fuel Cleaning}

Prior to admission to any catalyst (to fuel cell, to reformer or shift, see also Fig. 1), it is wise to remove a maximum of impurities (Table 1) that may poison these catalysts downstream. This applies to gaseous fuels as well as to solid or liquid primary fuels after their gasification. Cleaning can be accomplished specifically per impurity or in more general fashion. An example for the first case is sulphur removal by reaction over a heated $\left(350^{\circ} \mathrm{C}\right) \mathrm{ZnO}$-scrubber, or an acid wash to capture ammonia, for instance.

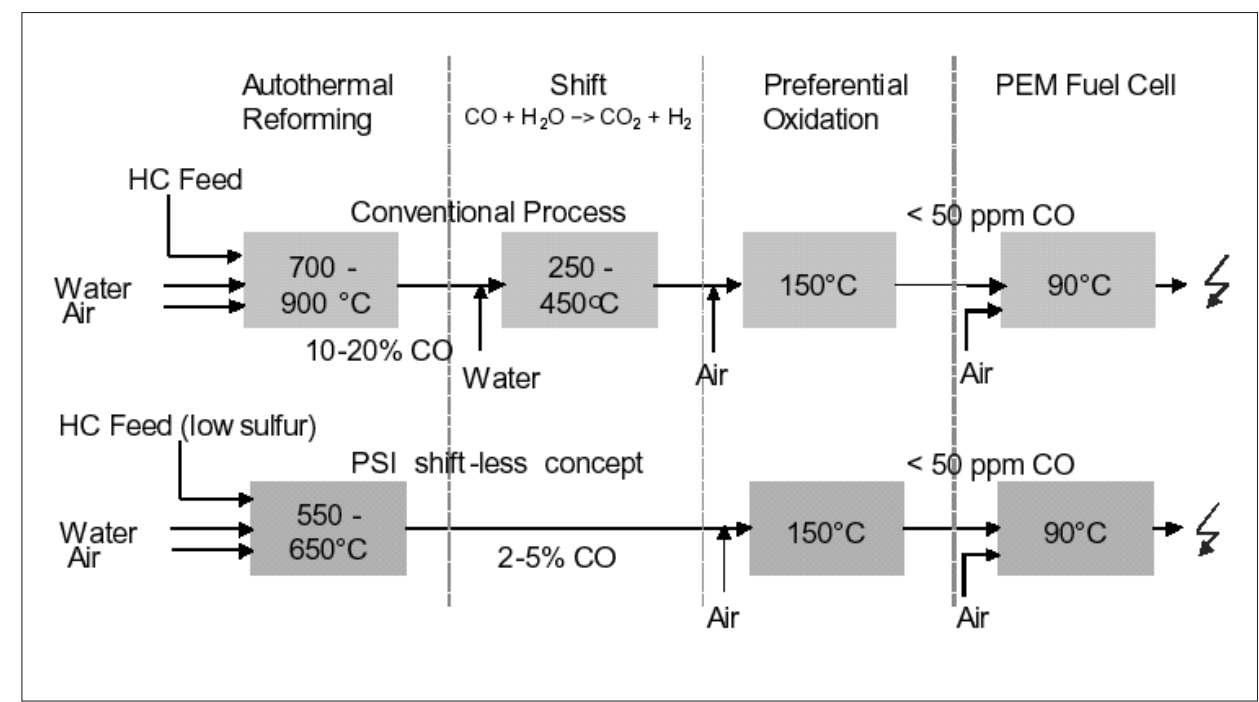

Fig. 1. Main steps in the reforming of gasoline to produce fuel cell-grade hydrogen. Top: state-of-the art process including autothermal reforming, one or two shift reactors, a preferential $\mathrm{CO}$ oxidation unit, and the PEFC. Bottom: PSI's 'shift-less' concept operating at lower reformer temperatures, producing less $\mathrm{CO}$, and thus able to omit the shift reactors. 
The second case, generally applied, is adsorption on active carbon traps. Active carbon can be treated to specifically retain sulphurous compounds, halides or substances like ammonia, at room temperature [2]. Principally, tolerance levels per catalyst for each impurity require experimental determination. For PEFCs, these levels may be as low as $10 \mathrm{ppb}$ for $\mathrm{H}_{2} \mathrm{~S}, 0.1 \mathrm{ppm}$ for $\mathrm{NH}_{3}$ (acidic electrolyte) and $50 \mathrm{ppm} \mathrm{CO}$ (towards $\mathrm{Pt}$ catalyst). The latter important case, carried out in fact after the fuel conversion steps (reforming, shift), is discussed in detail in the next section. For SOFCs (Ni catalyst), they are believed to be $1 \mathrm{ppm}$ for halides and $10 \mathrm{ppm}$ for $\mathrm{H}_{2} \mathrm{~S}$ [3]. Ammonia to SOFCs, on the contrary, acts as a fuel [4].

The three major high temperature (650-950 ${ }^{\circ} \mathrm{C}$ ) processing options are

steam reforming

$\mathrm{CH}_{4}+\mathrm{H}_{2} \mathrm{O} \Rightarrow 3 \mathrm{H}_{2}+\mathrm{CO}$

$\mathrm{CO}_{2}$ reforming

$\mathrm{CH}_{4}+\mathrm{CO}_{2} \Rightarrow 2 \mathrm{H}_{2}+2 \mathrm{CO}$

$\Delta \mathrm{H}^{0}=247.3 \mathrm{~kJ}$

partial oxidation

$$
\mathrm{CH}_{4}+\frac{1}{2} \mathrm{O}_{2} \Rightarrow 2 \mathrm{H}_{2}+\mathrm{CO}
$$$$
\Delta \mathrm{H}^{0}=-35.7 \mathrm{~kJ}
$$

Mixing air (or oxygen) and water vapour is also employed. Tuning the reaction such that energy requirement (endothermic reforming with $\mathrm{H}_{2} \mathrm{O}$ or $\mathrm{CO}_{2}$ ) is more or less

\section{Fuel Processing}

balanced with energy release (exothermic combustion with air or $\mathrm{O}_{2}$ ), one can achieve so-called autothermal reforming (ATR). A similar case, treated in detail elsewhere [5], is air addition to biogas, which can be interpreted as methane mixed reforming with $\mathrm{CO}_{2}$ and $\mathrm{O}_{2}$. The reactions do not go until stoichiometric completion: equilibrium concentrations are determined by the temperature (see Fig. 2).

Steam reforming (STREF) is preferably used for larger systems, since it yields the richest $\mathrm{H}_{2}$ outlet. It is least prone to carbon formation. For small systems, partial oxidation (POX) is preferred for simplicity (no clean water source necessary), low maintenance and lower cost, but it implies an electrical efficiency loss. POX is also used for liquid fuels. Both technologies are sulphur-sensitive.

Thermodynamically, solid carbon can be deposited from three reactions:

methane dissociation (pyrolysis)

$\mathrm{CH}_{4} \Rightarrow \mathrm{C} \downarrow+2 \mathrm{H}_{2}$

CO disproportionation (Boudouard)

$2 \mathrm{CO} \Leftrightarrow \mathrm{C} \downarrow+\mathrm{CO}_{2}$

reverse gasification

$\mathrm{CO}+\mathrm{H}_{2} \Leftrightarrow \mathrm{C}+\mathrm{H}_{2} \mathrm{O}$

Excess of steam prevents carbon deposits. Carbon formation is kinetically suppressed at low temperatures.

For low temperature fuel cells, the $\mathrm{CO}$ content after reforming has to be further reduced. This is achieved by adding more water vapour. This reacts with $\mathrm{CO}$ at low temperatures to $\mathrm{CO}_{2}$ and $\mathrm{H}_{2}$, in the (water gas) shift reaction (WGS)
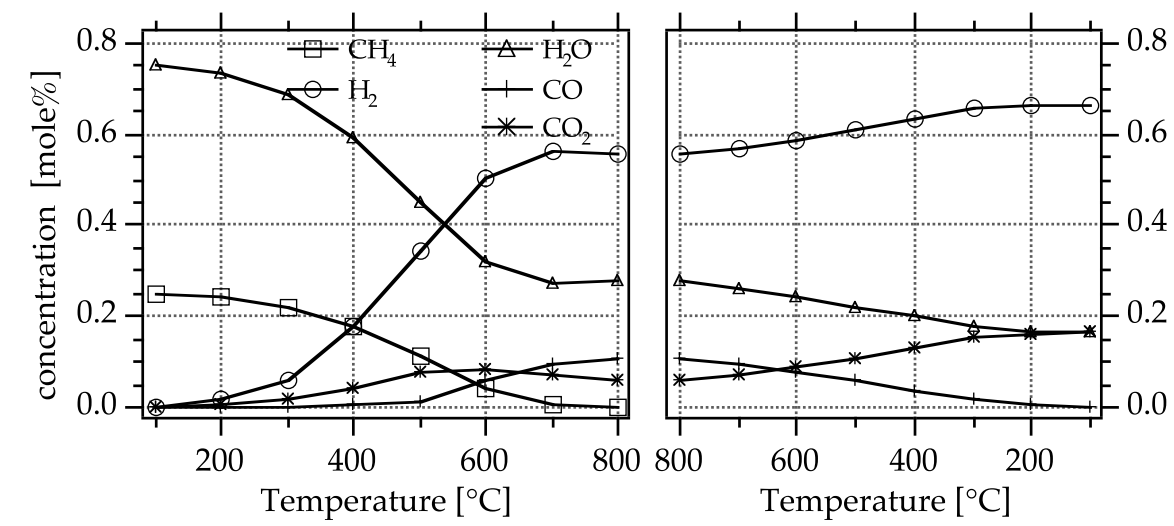

Fig. 2. Equilibrium gas concentrations (natural gas + water vapour, $S / C=3$ ) as a function of temperature during reforming (heat-up, left) and shift (cool down, right) processing (after [7]). In reality water is added before the reformer, and again before the shift. On the right hand side plot, reverse steam reforming over the shift catalysts is not taken into account $\left(\mathrm{CH}_{4}=0\right)$.
$\mathrm{CO}+\mathrm{H}_{2} \mathrm{O} \Rightarrow \mathrm{H}_{2}+\mathrm{CO}_{2}$

In total, i.e. using a steam-to-carbon ratio ('S/C') equal to 2 , one can obtain :

$\mathrm{CH}_{4}+2 \mathrm{H}_{2} \mathrm{O} \Rightarrow 4 \mathrm{H}_{2}+\mathrm{CO}_{2}$

The shift reaction proceeds in two steps, one called high temperature ( $c a$. 330-450 ${ }^{\circ} \mathrm{C}$ ), on $\mathrm{FeCr}$ catalyst, the other low temperature $\left(180-250{ }^{\circ} \mathrm{C}\right)$, on $\mathrm{CuO}-\mathrm{ZnO}$ catalysts, to reduce the $\mathrm{CO}$ level to $3 \mathrm{vol} \%$, then $0.5 \mathrm{vol} \%$ respectively. The effect on the equilibrium concentrations is shown in Fig. 2.

Fig. 3 shows the free enthalpy change, $\Delta \mathrm{G}^{\circ}$, of the important reactions indicated above, crossing zero in the temperature region between 600 and $800{ }^{\circ} \mathrm{C}$.

Fig. 4 shows the minimal amount of reforming agent $\left(\mathrm{H}_{2} \mathrm{O}, \mathrm{CO}_{2}, \mathrm{O}_{2}\right)$ necessary to add to $\mathrm{CH}_{4}$, as simplest hydrocarbon and main constituent of natural gas, in order to thermodynamically avoid carbon deposition, as a function of temperature. An ATR case $\left(\mathrm{O}_{2} / \mathrm{C}=0.25\right.$, variable $\left.\mathrm{S} / \mathrm{C}\right)$ is also indicated.

The temperature zone of maximal risk for steam reforming $\left(500-700{ }^{\circ} \mathrm{C}\right)$ can be understood from the simultaneous positive trend for graphite formation for all three reactions (4), (5), (6), as illustrated in Fig. 5.

When the reforming reaction takes place in thermal contact with a hot fuel cell stack (SOFC), we deal with integrated reforming. If the reformer is thermally separated from the stack (PEFC), the reforming is termed external. Internal reforming shows higher overall efficiency, which is one of the advantages of the high temperature cells. Table 2 compares SOFC system efficiencies calculated for different fuel feeds [6], where steam reformed methane supersedes hydrogen because of lower entropy loss. Stack operating parameters have been taken as equivalent for all considered fuel cases: $800{ }^{\circ} \mathrm{C}$ operating temperature, $80 \%$ fuel conversion, identical and realistic $\mathrm{I}-\mathrm{V}$ behaviour $\left(0.24 \mathrm{~A} / \mathrm{cm}^{2}\right.$ at $\left.0.65 \mathrm{~V}\right)$. The added benefit, owing to the endothermicity of the reforming reactions, is adequate cooling of the hot stack, so that air excess $(\lambda)$, used at the fuel cell cathode side to remove heat, can be reduced (Table 2).

With SOFC, we can further distinguish indirect internal reforming from direct internal reforming, depending on whether the reformer catalyst is adjacent to or within the anode chamber. In principle, reforming directly on the $\mathrm{Ni}$ anode catalyst is possible (in situ reforming). In a hydrocarbon fed fuel cell, in situ reforming forcefully takes place because $\mathrm{H}_{2} \mathrm{O}$ and $\mathrm{CO}_{2}$ are generated as oxidation products; the reforming reactions of hydrocarbons on nickel are much faster than the direct oxidation reaction of hydrocarbons.

The evolution with temperature of natural gas conversion to $\mathrm{H}_{2}$-rich (CO-poor) re- 


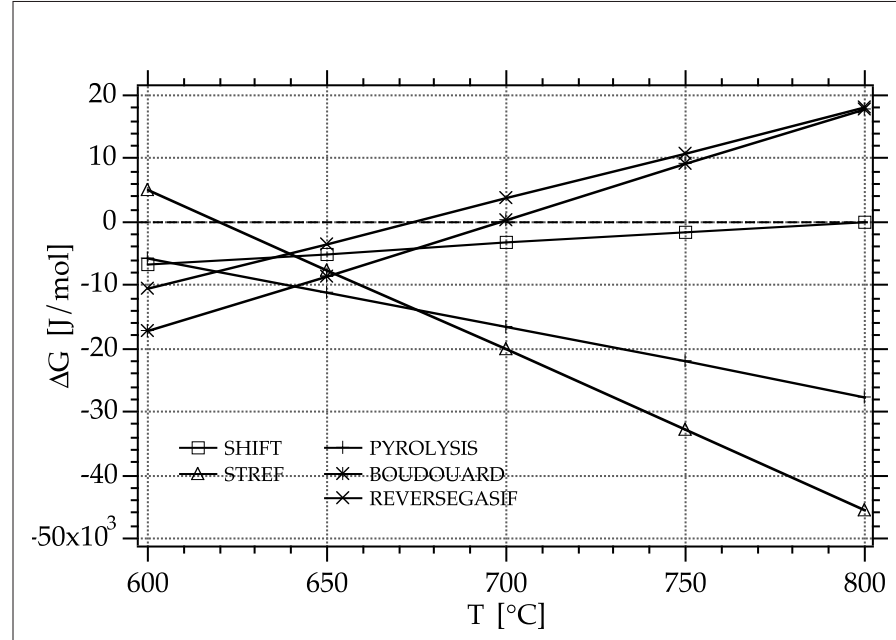

Fig. 3. Free enthalpy changes at high temperature for chemical reactions involving $\mathrm{CH}_{4}, \mathrm{H}_{2}$ and $\mathrm{CO}$ fuels

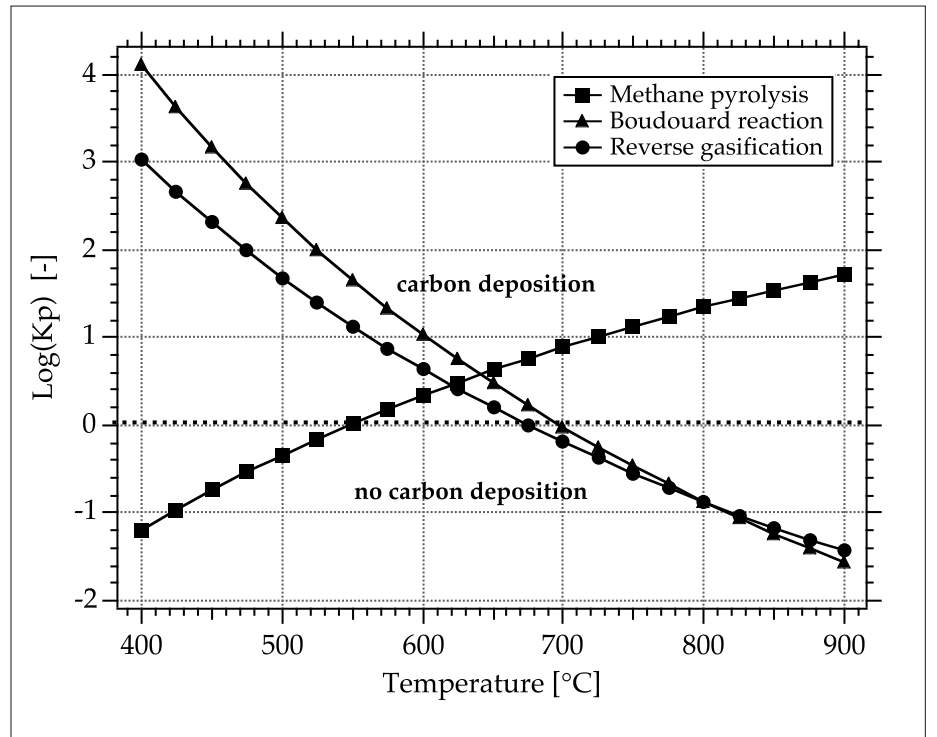

Fig. 5. Trend for graphite formation, as a function of temperature, of the three reactions (4), (5), (6). Note the overlap $(\log K>0)$ in the temperature region of maximal risk at $550-650^{\circ} \mathrm{C}$.

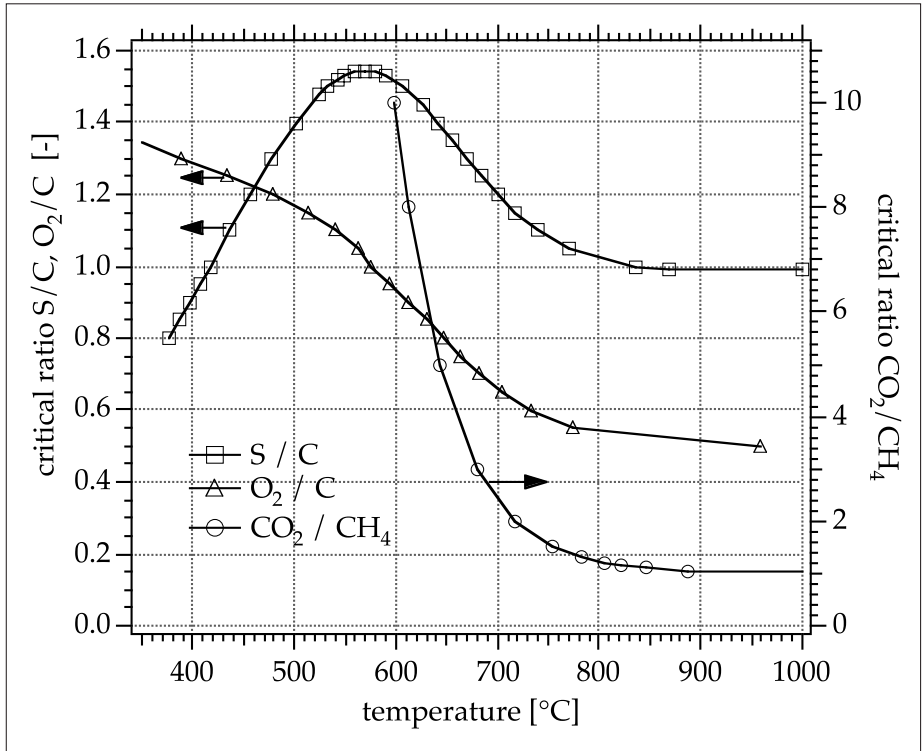

Fig. 4. Minimal amount of reforming agent $\left(\mathrm{H}_{2} \mathrm{O}, \mathrm{CO}_{2}, \mathrm{O}_{2}\right)$ required, according to reactions (1), (2), (3), to suppress carbon deposition (reactions (4), (5), (6)) as a function of temperature. A mixed case of autothermal reforming, ATR, $\left(\mathrm{O}_{2} / \mathrm{C}=0.25, \mathrm{~S} / \mathrm{C}\right.$ variable $)$ is also shown.

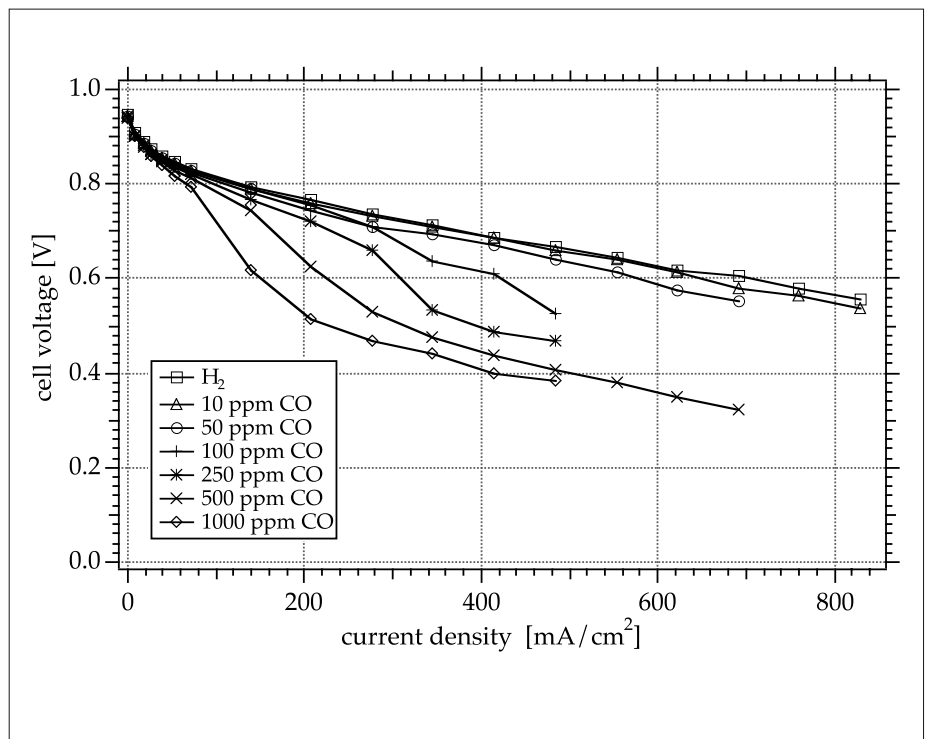

Fig. 6. Effect of $\mathrm{CO}$ concentration in $\mathrm{H}_{2}$, on PEFC cell. $\mathrm{T}_{\text {cell }}=80^{\circ} \mathrm{C}, \mathrm{p}=2$ bar. PtRu anode (C-type), Pt cathode (C-type), N-112 membrane. Air to cathode, $\lambda=2$. formate fuel, going through the steps of high-temperature steam reforming and subsequent low-temperature shift is depicted in Fig. 2 (after [7]). For the right-hand plot in this Fig., cooling down the reformate over shift catalysts, reverse steam reforming is no longer taken into account. In reality, water is added to the reformer inlet and again to the shift reactor. For clarity only the methane conversion is indicated in Fig. 2. The higher hydrocarbons contained in natural gas, being more reactive than methane, will be converted to syngas in the same process at lower temperatures according to

$\mathrm{C}_{\mathrm{n}} \mathrm{H}_{2 \mathrm{n}+2}+\mathrm{nH}_{2} \mathrm{O} \rightarrow(2 \mathrm{n}+1) \mathrm{H}_{2}+\mathrm{nCO}$
For PEFC using Pt as anode catalyst, $0.5 \%$ of $\mathrm{CO}$ after reforming and shift reactions remains too high, its content has to be further reduced. According to the accepted model [8], a $\mathrm{H}_{2}$ molecule adsorbed on two $\mathrm{Pt}$ sites is preferentially replaced by two CO molecules, at low temperatures. The anodic current reduction in the presence of $\mathrm{CO}$ can be expressed as

$$
\frac{i_{C O}}{i_{H_{2}}}=\left(1-\theta_{C O}\right)^{2}
$$

with $\theta_{\mathrm{CO}}$ being the fractional coverage of $\mathrm{CO}$ on Pt. For example, with $2.5 \% \mathrm{CO}$ in the gas stream, coverage is $31 \%$ even at 190
${ }^{\circ} \mathrm{C}$, and therefore current reduction $50 \%$. Fig. 6 shows the effect on the current-voltage output of a PEFC, at $80^{\circ} \mathrm{C}$, for $\mathrm{CO}$ concentrations between 10 and $1000 \mathrm{ppm}$, measured at PSI. Therefore extensive purification to suppress the $\mathrm{CO}$ content at least to a level of $50 \mathrm{ppm}$ is carried out, by alternative means of: physical $\mathrm{CO} / \mathrm{H}_{2}$ gas separation, using a thin $\mathrm{Pd}$ membrane on a support ( $\mathrm{Pd}$ is $100 \%$ selective to $\mathrm{H}_{2}$ permeation); methanation, converting $\mathrm{CO}$ into $\mathrm{CH}_{4}$, using $\mathrm{H}_{2}$ of the stream, on a specific catalyst and controlled temperature; selective or preferential oxidation (PROX), converting $\mathrm{CO}$ into $\mathrm{CO}_{2}$, by addition of a small quantity of air in the fuel stream over a spe- 
Table 2. Comparison of calculated SOFC system output for different fuel processing methods and different fuel feeds [6]. Same HHV input in all cases (269 kW). SOFC stack parameters were taken constant: $800{ }^{\circ} \mathrm{C}$ operating temperature, $80 \%$ fuel conversion, identical I-V behavior

\begin{tabular}{|llllll}
\hline Parameter & unit & $\begin{array}{l}\text { Biogas } \\
\text { Steam-Ref. }\end{array}$ & $\begin{array}{l}\text { Biogas POX } \\
\text { Sethane } \\
\text { Steam-Ref. }\end{array}$ & Hydrogen \\
S/C- ratio & - & 0.5 & - & 1.15 & - \\
$\mathrm{O}_{2} /$ C-ratio & - & - & 0.3 & - & - \\
net elec. efficiency & $\%$ & 48.66 & 42.94 & 49.20 & 42.58 \\
thermal efficiency & $\%$ & 39.58 & 46.36 & 36.98 & 45.63 \\
fuel cell generated heat & $\mathrm{kW}$ & 142.9 & 117.9 & 135.4 & 101.2 \\
reformer absorbed heat & $\mathrm{kW}$ & 78.2 & 29.4 & 71.1 & - \\
$\begin{array}{l}\text { air excess } \lambda \text { for cooling } \\
(\Delta \mathrm{T} \text { on stack = 200 K) }\end{array}$ & - & 3 & 4.5 & 3 & 6 \\
\hline
\end{tabular}

cific catalyst at $c a .150{ }^{\circ} \mathrm{C}$ (supported Au or $\mathrm{Ru}$ ). Even in the large excess of $\mathrm{H}_{2}$, oxygen will preferentially oxidize $\mathrm{CO}$. In reality, a $\mathrm{H}_{2}$ fraction will also be converted to $\mathrm{H}_{2} \mathrm{O}$. PROX is the method most often used.

The Pt-catalyst poisoning is due to the higher adsorption energy and the very slow oxidation rate of adsorbed $\mathrm{CO}$ molecules $\left(\mathrm{CO}_{\mathrm{ad}}\right)$ compared to the adsorbed $\mathrm{H}$-atoms $\left(\mathrm{H}_{\mathrm{ad}}\right)$ at the Pt catalyst sites. Exchange current densities $\left(\mathrm{j}_{\mathrm{O}}\right)$ are estimated to $\mathrm{j}_{\mathrm{o}}\left(\mathrm{H}_{2}\right)=$ $1 \mathrm{~mA} / \mathrm{cm}^{2}$ and $\mathrm{j}_{\mathrm{o}}(\mathrm{CO})=10^{-8} \mathrm{~mA} / \mathrm{cm}^{2}$ respectively. The $\mathrm{CO}$-poisoning can be diminished or even avoided by either decreasing the catalyst surface coverage of $\mathrm{CO}$ or promoting the catalytic oxidation rate of the $\mathrm{CO}_{\mathrm{ads}}$. Since adsorption is an exothermic reaction, the $\mathrm{CO}$-coverage decreases as a function of increasing cell temperature. In addition, the higher temperature enhances the oxidation rate of both $\mathrm{H}_{2}$ and CO. This is experimentally demonstrated in Fig. 7, for an increase of 80 to $100{ }^{\circ} \mathrm{C}$.
The electrooxidation of $\mathrm{CO}_{\text {ads }}$ is also promoted when $\mathrm{Pt}$ is alloyed with a second metal such as ruthenium ( $\mathrm{Ru})$. Ru plays the role as an O-donator for the electrooxidation of $\mathrm{CO}_{\mathrm{ad}}$ to $\mathrm{CO}_{2}$ at low anodic overpotentials. The alloying of Pt and Ru has also an electronic effect, making the CO-adsorption on Pt less favourable and decreasing the adsorption equilibrium constant of CO. The most CO-tolerant and stable bimetal electrocatalyst for $\mathrm{CO}$-electrooxidation is known to be PtRu. Apart from the PtRu composition, the morphology of the electrocatalyst, the catalyst support, the structure and the preparation technique of the electrode all have a strong influence on the final CO-tolerance. In situ oxidation of $\mathrm{CO}_{\mathrm{ad}}$ on the anode catalyst by adding a small amount of air to the fuel ('air-bleeding') is an additional efficient approach, illustrated in Fig. 8.

To date, the best solution appears to be a combination of all three methods, using a CO-tolerant anode electrode at relatively higher cell temperature, above $80{ }^{\circ} \mathrm{C}$, and pulsing of small amount of air.

\section{Examples from Swiss Fuel Cell Research}

\subsection{Shiftless Gasoline Reforming to $\mathrm{H}_{2}$ for PEFC}

At PSI, a new precious metal catalyst allowing low-temperature reforming $\left(550-650{ }^{\circ} \mathrm{C}\right.$ ) of hydrocarbons was developed. It was tested to obtain $\mathrm{H}_{2}$ from reforming of gasoline fuel, with the advantage of maintaining the present fuel infrastructure. Gasoline reforming provides a good method to produce hydrogen for fuel cells [9]. The stoichiometry for the reaction of gasoline with oxygen and water may be written as:

$\mathrm{C}_{7.3} \mathrm{H}_{12.6}+\mathrm{nO}_{2}+(14.6-2 \mathrm{n}) \mathrm{H}_{2} \mathrm{O}+4 \mathrm{nN}_{2}$
$\rightarrow\left(20.9-2 \mathrm{n}_{2} \mathrm{H}_{2}+7.3 \mathrm{CO}_{2}+4 \mathrm{nN}_{2}\right.$

Depending on the application, gasoline may be reacted with water only (steam reforming, $n=0$ ), with air only (partial oxidation, $n=3.65$ ), or with a mixture of air and water (autothermal reforming, $\mathrm{n}=$ 1.825). A comparison of the technologies for iso-octane reforming is given in Table 3 . The route of choice is autothermal reforming (ATR), because it allows for fast start-up and high reformer efficiencies. Fig. 1 depicts the process steps necessary to produce PEFC-grade hydrogen from gasoline, compared to the more conventional approach.

Most developments focus on high-temperature reforming followed by high- and low-temperature shift reactors to reduce the $\mathrm{CO}$ content and to produce more hydrogen [10]. Final CO cleanup is achieved in a preferential oxidation reactor, where $\mathrm{CO}$ is oxidized to $\mathrm{CO}_{2}$. PSI's 'shift-less' concept oper-

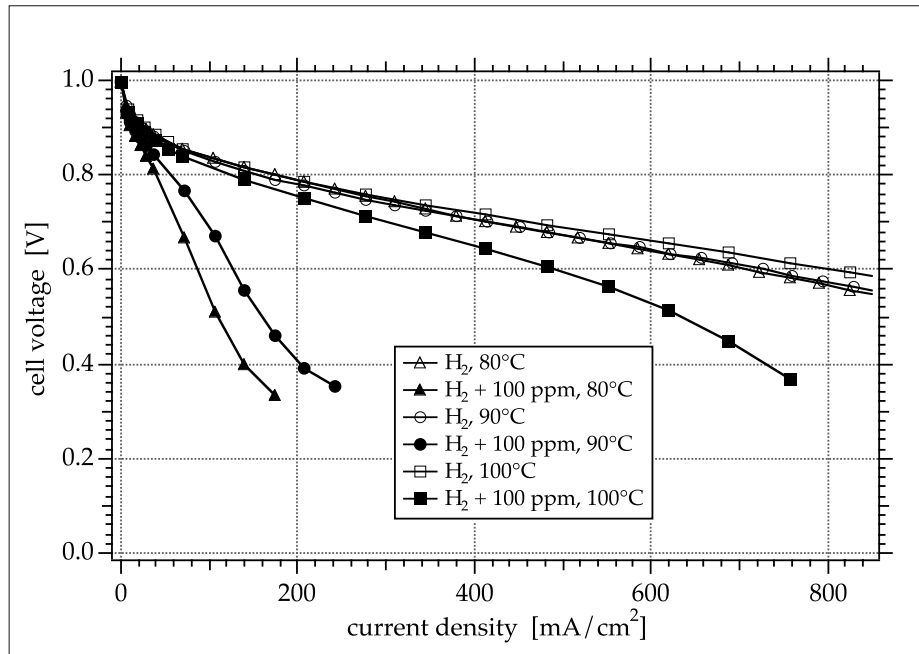

Fig. 7. Effect of temperature $\left(80 / 90 / 100{ }^{\circ} \mathrm{C}\right)$ on CO-tolerance $(100 \mathrm{ppm}$ in $\mathrm{H}_{2}$ fuel) for PEFC cell. $\mathrm{P}=3$ bar. Pt electrodes (C-type), $\mathrm{N}-115$ membrane. $\mathrm{O}_{2}$ to cathode, $\lambda=1.5$.

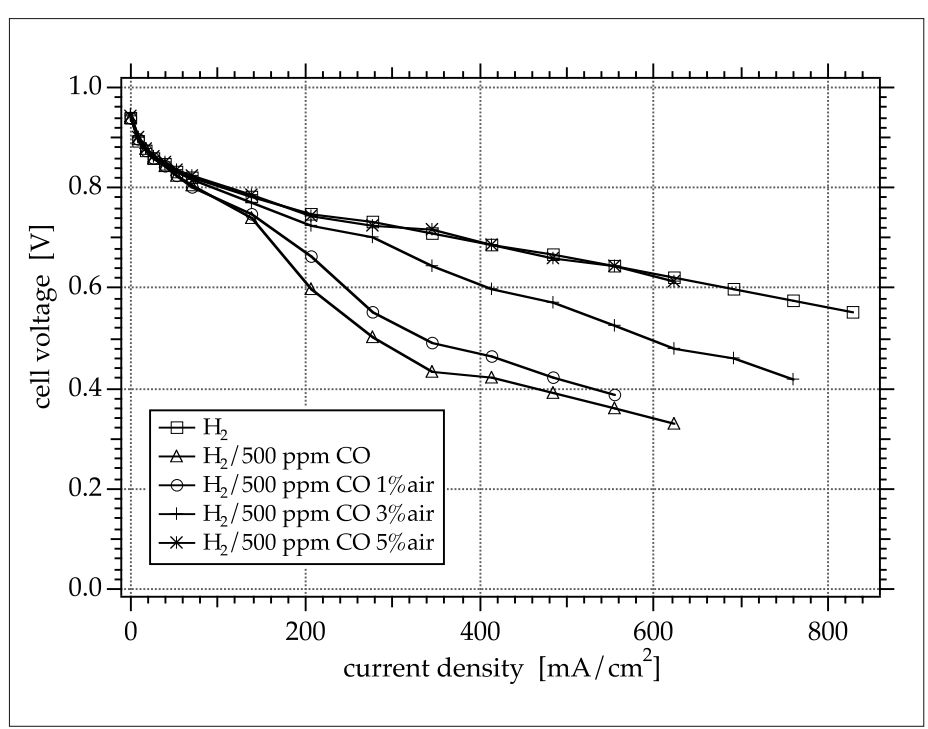

Fig. 8. Effect of air-addition (1/3/5\%) to the fuel for in situ CO oxidation (500 ppm in $\mathrm{H}_{2}$ ) in a PEFC cell. $\mathrm{P}=2$ bar. PtRu anode (C-type), Pt cathode (Ctype), $\mathrm{N}-112$ membrane. Air to cathode, $\lambda=2$. 
Table 3. Trade-off for reforming technology (iso-octane feed)

\begin{tabular}{|c|c|c|c|c|c|c|c|}
\hline \multirow[t]{2}{*}{ Variant } & \multicolumn{3}{|c|}{ Feed ratios } & \multicolumn{2}{|c|}{ Products (theor.) } & \multirow{2}{*}{$\begin{array}{l}\text { Efficiency } \\
\varepsilon_{\max }\end{array}$} & \multirow{2}{*}{$\begin{array}{l}\text { Conc. } \\
\mathrm{H}_{2} \\
{[\% \text { dry }}\end{array}$} \\
\hline & $\mathrm{S} / \mathrm{C}$ & $\mathrm{O}_{2} / \mathrm{C}$ & $\begin{array}{l}\Delta \mathrm{H}^{\circ} \\
{[\mathrm{kJ} / \mathrm{mol}]}\end{array}$ & $\mathrm{vCO}_{2}$ & $v \mathrm{H}_{2}$ & & \\
\hline STREF & 2 & 0 & 946 & 8 & 25 & 1.2 & 76 \\
\hline ATR & 1.5 & 0.25 & -22 & 8 & 21 & 1 & 57 \\
\hline POX & 0 & 0.5 & -2926 & 8 & 9 & 0.43 & 18 \\
\hline
\end{tabular}

ates at lower temperatures in the reformer, but using more water than would be required for autothermal reforming according to reaction (11), producing much less $\mathrm{CO}$, and is thus able to omit the shift reactors [11]. The challenges are:

a) To find a catalyst active for gasoline reforming at lower temperatures, producing high yields of hydrogen.

b) To reduce the $\mathrm{CO}$ content from $5 \%$ to less than 50 ppmv (> 99.9\% conversion) without losing much hydrogen.

The main benefit of the 'shift-less' concept is the simpler design with only two instead of four catalytic reactors, leading to faster start-up and response times. To demonstrate the technical feasibility of PSI's 'shift-less' concept, a lab-scale fuel processor and a link up to a PEFC was built. The goals were:

a) To produce a hydrogen-rich reformate gas with $<50$ ppm of CO from sulphurfree gasoline.

b) To study the influence of a real reformate gas on the PEFC performance.

Building on earlier results from methanol and hydrocarbon reforming [9][11], a continuous fixed-bed fuel processor, consisting of ATR reactor and a preferential oxidation $(\mathrm{PROX})$ reactor was built. Water and gasoline $(\mathrm{RON}=95, \mathrm{~S}<1 \mathrm{ppm})$ were pumped as liquids, vaporized and mixed with air, before entering the ATR reactor (I.D. $=16 \mathrm{~mm}, \mathrm{~L}=482 \mathrm{~mm}$ ). The reactor was filled with $16 \mathrm{~g}$ of $1 \% \mathrm{Rh} / \mathrm{CeO}_{2} / \mathrm{ZrO}_{2}$ powder catalyst, diluted with quartz sand. The reformate gas was fed to the PROX reactor via a heated transfer line, where it was mixed with oxygen. The PROX reactor was of annular type (annular gap $=2.75 \mathrm{~mm}, \mathrm{~L}=200 \mathrm{~mm}$ ), which facilitates the heat dissipation. The PROX reactor was filled with $6 \mathrm{~g}$ of $5 \% \mathrm{Ru} / \mathrm{CeO}_{2} / \mathrm{ZrO}_{2}$ powder catalyst, diluted with quartz sand. Both ATR and PROX reactors were heated electrically for start-up and for heat loss compensation. Movable thermocouples in thermowells were placed in both reactors to measure the temperature profile of the catalyst during reaction. Fig. 9 shows a picture of the lab-scale fuel processing unit.

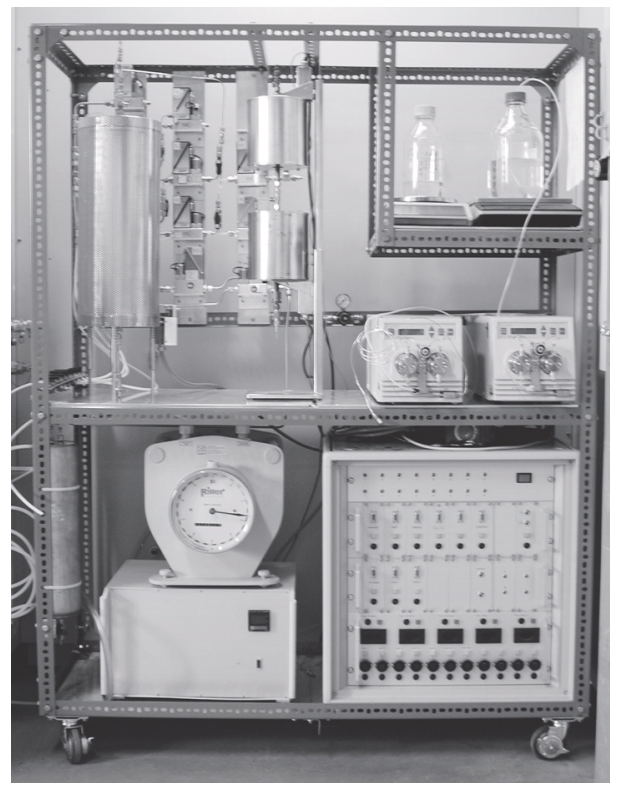

Fig. 9. Lab-scale gasoline fuel processor consisting of an autothermal reformer and a preferential oxidation reactor

Gas composition was analyzed on-line for $\mathrm{CH}_{4}, \mathrm{CO}_{2}, \mathrm{CO}, \mathrm{H}_{2}, \mathrm{O}_{2}, \mathrm{~N}_{2}$ on a $\mathrm{HP} 6890$ gas chromatograph (GC) using a thermoconductivity detector (TCD) and a two-column switching system with helium as the carrier gas. Unreacted hydrocarbons in the reformate gas were analyzed on the same GC with a flame ionization detector (FID). Total volumetric flow of reformate was determined by a wet test meter. The fuel processor was connected to a $30 \mathrm{~cm}^{2}$ PEFC with meander flow field graphite plates [12][13]. A catalyst-coated membrane where the catalyst material (PtRu as anode and Pt as cathode) was directly applied on the electrolyte membrane, Nafion ${ }^{\circledR} 112$, and two different gas diffusion layers were used as membrane electrode assembly (MEA). After the PROX the reformate gas was fed through a humidifier into the fuel cell.

Process parameters temperature (T), WHSV (hydrocarbon weight hourly space velocity, $\mathrm{g}^{-1} \mathrm{~h}^{-1}$ ), and $\mathrm{S} / \mathrm{C}$ ( steam-to-carbon molar ratio) were varied to minimize $\mathrm{CO}$ concentration in the reformate gas stream. The best conditions for minimizing the $\mathrm{CO}$ concentration after the PROX unit are summarized in Table 4.

The $\mathrm{CO}$ concentration was reduced below the detection limit of the analysis method (36 ppmv). This dry reformate gas was directed to the fuel cell. The fuel processor and fuel cell were operated for two hours at stable conditions.

Good fuel cell performance was demonstrated under the optimized reformer operating conditions (Table 4). The fuel cell polarization curves for hydrogen-rich reformate gas with a composition of $32 \% \mathrm{H}_{2}, 29 \% \mathrm{CO}_{2}$, $13 \% \mathrm{CH}_{4}, 27 \% \mathrm{~N}_{2},<36 \mathrm{ppm} \mathrm{CO}$ as fuel, and $\mathrm{O}_{2}$ or air as oxidant, are exhibited in Fig. 10. At a current density of $500 \mathrm{~mA} / \mathrm{cm}^{2}$, cell voltages of $560 \mathrm{mV}$ and $700 \mathrm{mV}$ were obtained for operation with air and oxygen, respectively. Cell voltage proved to be essentially stable and similar to the operation with pure $\mathrm{H}_{2}$; only a small drop of the cell voltage (40 $\mathrm{mV}$ ) was observed with reformate operation due to CO poisoning [14].

The total time on stream of the fuel processor was approximately $140 \mathrm{~h}$. No signs of deactivation were observed. Future work will aim at using metal monoliths instead of a powder catalyst and focus on the heat integration of PROX reactor with fuel evaporator.

Table 4. Best operating conditions for minimizing $\mathrm{CO}$ concentration in the reformate gas. $\mathrm{p}=4$ bar.

\begin{tabular}{|c|c|}
\hline \multicolumn{2}{|l|}{ POX conditions } \\
\hline $\begin{array}{l}\text { Reformer outlet } \\
\text { temperature }\end{array}$ & $610^{\circ} \mathrm{C}$ \\
\hline $\mathrm{S} / \mathrm{C}$ & 2.86 \\
\hline $\mathrm{O} / \mathrm{C}$ & 0.57 \\
\hline WHSV & $0.5 g_{\text {gasoline }} /\left(g_{\text {cat. }} h\right)$ \\
\hline GHSV & $4^{\prime} 738 \mathrm{~h}^{-1}$ \\
\hline \multicolumn{2}{|l|}{ PROX conditions } \\
\hline Inlet temperature & $140^{\circ} \mathrm{C}$ \\
\hline $\mathrm{O}_{2} / \mathrm{CO}$ & 1.24 \\
\hline GHSV & $12^{\prime} 634 \mathrm{~h}^{-1}$ \\
\hline \multicolumn{2}{|c|}{ Results (after PROX, dry) } \\
\hline $\mathrm{H}_{2}$ & $32 \%$ \\
\hline $\mathrm{CO}_{2}$ & $29 \%$ \\
\hline $\mathrm{CH}_{4}$ & $13 \%$ \\
\hline $\mathrm{N}_{2}$ & $27 \%$ \\
\hline $\mathrm{CO}$ & $<36$ ppmv \\
\hline \multicolumn{2}{|c|}{ Carbon conversion $\left(\mathrm{C}_{2+}\right) 100 \%$} \\
\hline CO conversion & $>99.93 \%$ \\
\hline $\mathrm{H}_{2}$ loss & $27 \%$ \\
\hline $\mathrm{H}_{2}$ yield & $\begin{array}{l}7.5 \mathrm{~mol} \\
\mathrm{H}_{2} / \mathrm{mol} \mathrm{C}_{7.3} \mathrm{H}_{12.6}\end{array}$ \\
\hline Reformate (dry) & $47 \mathrm{l} / \mathrm{h}$ \\
\hline
\end{tabular}




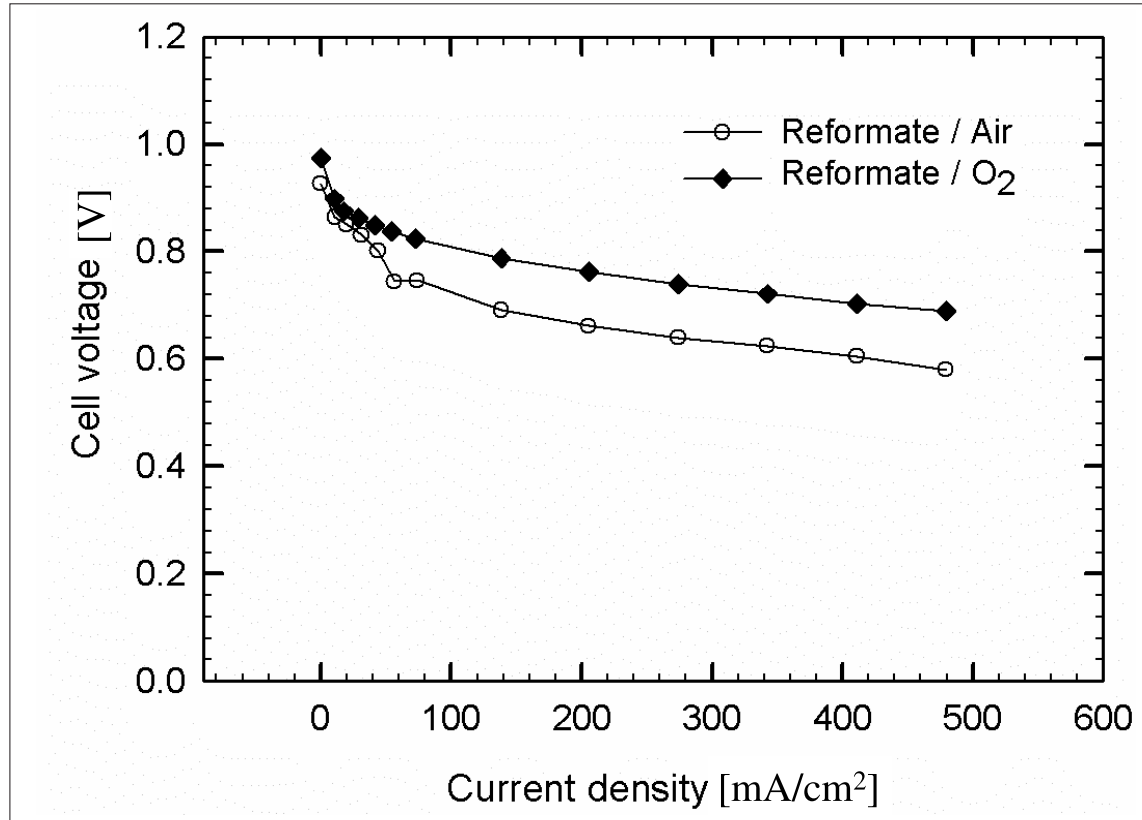

Fig. 10. Fuel cell polarization curves for reformate gas as fuel, and $\mathrm{O}_{2}$ or air as oxidant. $\mathrm{T}_{\text {cell }}=60^{\circ} \mathrm{C}$. $\mathrm{T}_{\text {hum }}$, cathode $=35^{\circ} \mathrm{C}, \mathrm{T}_{\text {hum }}$, anode $=35^{\circ} \mathrm{C} . \lambda_{\text {fuel }}=1.5, \lambda_{\mathrm{O}_{2}}=1.5$, and $\lambda_{\text {air }}=2 . \mathrm{P}_{\text {anode }}=\mathrm{P}_{\text {cathode }}=1$ bar $_{\mathrm{a}}$.

Table 5. Mixtures of five micro-impurities used in the CPO catalyst test bench at ZHW.

$\begin{array}{lll}\mathrm{H}_{2} \mathrm{~S} & 30^{\prime} 000 \mathrm{ppm} & \text { in } \mathrm{CO}_{2} \\ \mathrm{HCl} & 1500 \mathrm{ppm} & \text { in } \mathrm{CO}_{2} \\ \mathrm{R} 123 & 1200 \mathrm{ppm} & \text { in } \mathrm{CO}_{2} \\ \mathrm{NH}_{3} & 1200 \mathrm{ppm} & \text { in } \mathrm{N}_{2} \\ \mathrm{SiH}_{4} & 240 \mathrm{ppm} & \text { in } \mathrm{N}_{2}\end{array}$

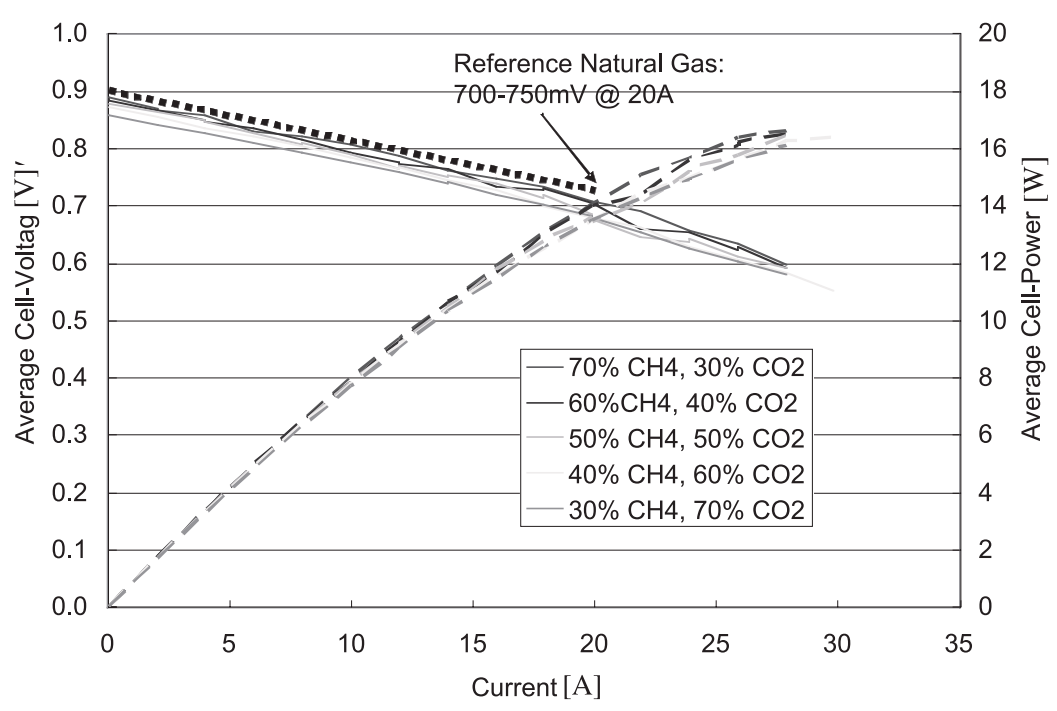

Fig. 11. Voltage-current output of 5 -cell SOFC stack ( $100 \mathrm{~cm}^{2}$ active area), ca. $900{ }^{\circ} \mathrm{C}$ (Sulzer HEXIS) with synthetic biogas, i.e. $\mathrm{CH}_{4} / \mathrm{CO}_{2}$-mixtures in the proportions $30 / 70$ to $70 / 30$ [2]

\subsection{Biogas Processing for SOFC}

Sulzer HEXIS (Winterthur) and ZHW (Zürcher Hochschule Winterthur) have been collaborating several years on catalytic partial oxidation (CPO) of natural gas and biogas. Because of their exothermicity, CPO converters run thermally self-sustaining. The amount of oxygen used is given by the air ratio $\lambda(=1$ for total oxidation).

One of the main problems with respect to long-term operation of the $\mathrm{CPO}$ catalyst is soot formation. Therefore, the theoretical $\lambda$ of 0.25 (reaction 3 ) is slightly increased to 0.27 .
Because of its simple construction and low maintenance requirements, $\mathrm{CPO}$ is the method of choice for fuel processing used in SOFC series products at Sulzer HEXIS.

HEXIS SOFC systems with CPO catalysis have been operated for about $30^{\prime} 000 \mathrm{~h}$ cumulated service time. Natural gas as fuel is the focus of HEXIS development. Investigations concentrate on durability and stability of the process under real conditions [15].

A high $\mathrm{CO}_{2}$ concentration and a variety of micro-impurities as shown in Table 5 are the main differences of biogas compared to natural gas. The high $\mathrm{CO}_{2}$ concentration affects the catalytic partial oxidation (CPO) of biogas mainly by the changes in thermodynamic equilibrium. Fig. 11, showing the current-voltage response of a Sulzer HEXIS 5cell SOFC stack tested with synthetic biogas $\left(\mathrm{CH}_{4} / \mathrm{CO}_{2}\right.$ mixture only, no impurities), demonstrates a negligible effect due to the $\mathrm{CO}_{2}$ dilution of the fuel [2]. This is important in the valorisation of biogas with fuel cells compared to engines, for instance, which do not run on diluted fuel [5]. Micro-impurities on the other hand have strong influences on the behaviour and lifetime of the catalyst. Knowing the tolerance of the process to every micro-impurity in the fuel is essential.

The ZHW test stand consists of four supply lines $\left(\mathrm{CH}_{4}\right.$, air, $\mathrm{CO}_{2}$ and microimpurities either in $\mathrm{CO}_{2}$ or $\mathrm{N}_{2}$ ) and a nitrogen flush line. The methane line (which in fact was natural gas) was desulphurised to avoid overlapping influences with the micro-impurities. $\mathrm{CO}_{2}$ was added to simulate a biogas like matrix.

The mass flow of each supply line is controlled and recorded. The zone in front of the reactor is electrically heated to get the reaction started. After ignition, the electric oven is turned off and the reaction proceeds autothermally. To get a detailed view of the temperature distribution along the length of the catalyst, six thermocouples are installed in the catalysts interior (at 0, 5, 10, 20, 40 and $70 \mathrm{~mm}$, indicated as T_00, T_05 etc.). The product gases are analyzed by gas chromatography.

The five substances listed in Table 5 represent the major micro-impurities. They were chosen with respect to availability and handling of the chemicals. The impurities were prepared as mixtures with $\mathrm{CO}_{2}$ (where possible) or with $\mathrm{N}_{2}$ as shown in the Table.

All experiments were carried out with the same parameters: $1500 \mathrm{~W}$ power input, 0.27 air ratio $(\lambda)$ and 40 vol\% $\mathrm{CO}_{2}$. Before and after each experiment a reference point with pure simulated biogas $\left(60 \% \mathrm{CH}_{4} / 40 \%\right.$ $\mathrm{CO}_{2}$ ) was measured. Thus, it was possible to detect an eventual degradation of the catalyst during the tests with the different impurities.

In addition to power input and air ratio cycles, the dynamic test was interrupted 


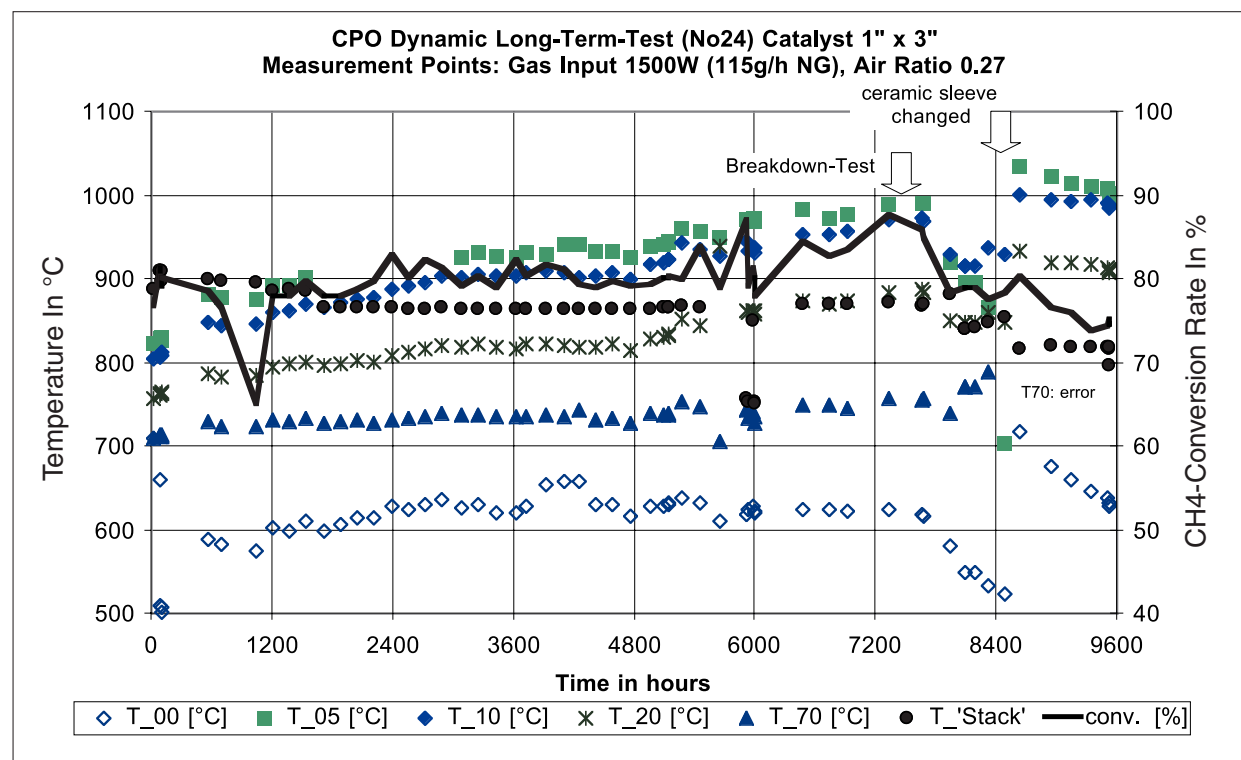

Fig. 12. Example for a long term CPO test at Sulzer HEXIS. T_00, T_05 etc. indicate temperatures at $0 \mathrm{~mm}, 5 \mathrm{~mm}$, etc. in the catalyst bed.

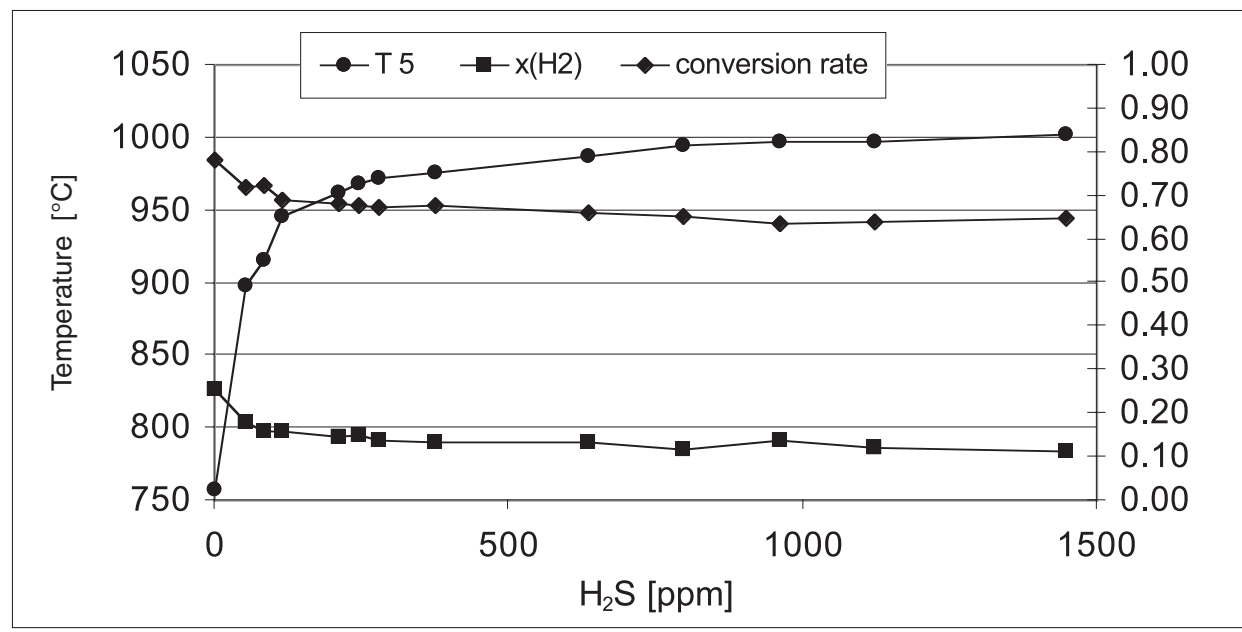

Fig. 13. Temperature, hydrogen fraction and conversion rate development depending on the $\mathrm{H}_{2} \mathrm{~S}$ concentration in simulated biogas

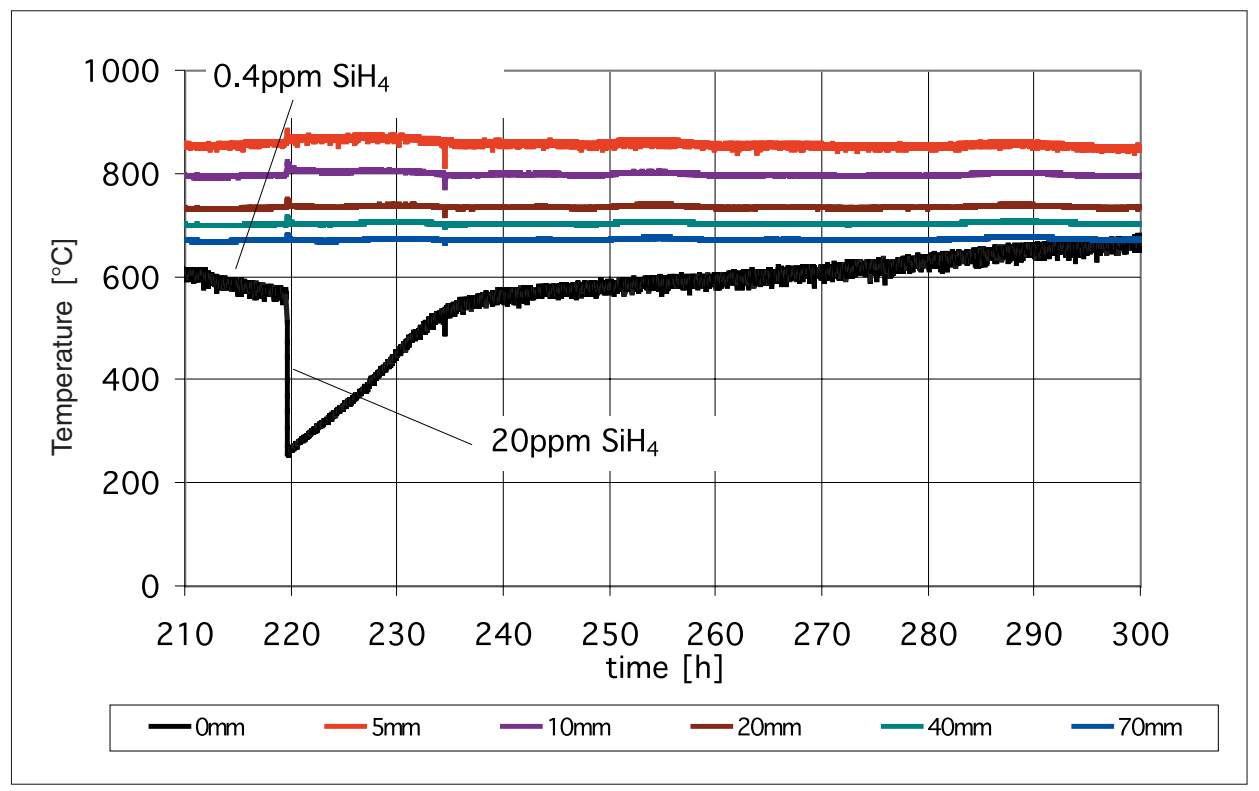

Fig. 14. Temperatures at different catalyst heights during poisoning by 0.4 and $20 \mathrm{ppm} \mathrm{SiH}_{4}$ and the different velocity of regeneration once a week. Afterwards the catalyst was cooled down and restarted again. Results of a $9000 \mathrm{~h}$ long term test are given in Fig. 12. The medium term demand of $8000 \mathrm{~h}$ lifetime could be fulfilled.

\section{$\mathrm{H}_{2} \mathrm{~S}$}

$\mathrm{H}_{2} \mathrm{~S}$ as a micro-impurity affects the reaction towards total oxidation, resulting in higher catalyst temperatures and less fuel conversion. Up to a $\mathrm{H}_{2} \mathrm{~S}$ concentration of $600 \mathrm{ppm}$ in the simulated biogas, the hot-spot temperature ( $\mathrm{T}$ at $5 \mathrm{~mm}$, ' $\mathrm{T} 5$ ') increased by about $270 \mathrm{~K}$ (Fig. 13), whereas the conversion rate and the hydrogen output decreased. Additional $\mathrm{H}_{2} \mathrm{~S}$ in the fuel caused no further considerable changes. This behaviour is reversible. A few hours after the $\mathrm{H}_{2} \mathrm{~S}$ stream is shut off, the catalyst reaches its former efficiency and temperature level. Thus, even if the conversion rate drops by approximately $20 \%$ and the temperature at the hot spot reaches $1000{ }^{\circ} \mathrm{C}$, the reaction, supplied with three times the normal concentration of $\mathrm{H}_{2} \mathrm{~S}$ in biogas, is not threatened with total breakdown. In conclusion, CPO is insensitive to concentration peaks and constant moderate $\mathrm{H}_{2} \mathrm{~S}$ loads.

\section{R123, $\mathrm{HCl}$, and $\mathrm{NH}_{3}$}

The response of the CPO reactor to the substance R123 (1,1-dichloro-2,2,2-trifluoromethane) and $\mathrm{HCl}$ is comparable to that to $\mathrm{H}_{2} \mathrm{~S}$, although the effect is smaller. $\mathrm{NH}_{3}$ does not affect the process at all. According to thermodynamic calculations, the hydrogen output is even increased due to the oxidation of ammonia to $\mathrm{N}_{2}$.

$\mathrm{SiH}_{4}$

$\mathrm{SiH}_{4}$ causes a very fast poisoning of the catalyst. At 20 ppm $\mathrm{SiH}_{4}$ (ca. $25 \mathrm{mg}$ sili$\mathrm{con} / \mathrm{m}^{3}$ ), the poisoning reaction proceeds through the catalyst at a rate of $20 \mathrm{~mm} / \mathrm{h}$. If the $\mathrm{SiH}_{4}$ flux is interrupted the catalyst regenerates completely at a rate of 0.25 $\mathrm{mm} / \mathrm{h}$. Feeding the catalyst with biogas containing $2 \mathrm{ppm}$ or $0.4 \mathrm{ppm} \mathrm{SiH}_{4}$, a much slower poisoning results. Fig. 14 shows the temperature at the catalyst entry $(0 \mathrm{~mm})$. At the beginning the catalyst is poisoned by $0.4 \mathrm{ppm} \mathrm{SiH}_{4}$. Afterwards $(\mathrm{t}=220 \mathrm{~h}), 20$ ppm is charged for a few minutes. The catalyst zone poisoned by $20 \mathrm{ppm}$ regenerates rapidly, whereas the front region (poisoned by $0.4 \mathrm{ppm}$ ) regenerates more slowly.

The way silicon is adsorbed on the catalyst depends on the silicon concentration in the fuel. This behaviour is indicated by the differences in the regeneration velocities. The catalyst used in this experiment was oversized, therefore no changes could be observed in the product gas composition and conversion rate.

Because of the very high poisoning potential of $\mathrm{SiH}_{4}$ no further investigations 
were made. The biogas supplied to a fuel cell has to be silicon free to guarantee stable fuel processing over years.

\section{Acknowledgements}

The CPO work at ZHW was partially supported through the KTI/CTI Innovation Promotion Agency at the Federal Office for Professional Education and Technology (OPET) under contract number 5166.1 FHS. The PSI authors thank F. Welti (Tamoil, Collombey) for providing sulphur-free gasoline.

Received: October 21, 2004

[1] J. Sfeir, 'Alternative anode materials for methane oxidation in solid oxide fuel cells', PhD Thesis Swiss Federal Institute of Technology Lausanne (EPFL) Nr. 2446, 2002.

[2] M. Jenne, J. Van herle, Y. Membrez, 'PilotAnlage Biogas HEXIS', Swiss Federal Energy Office Final Report, $\mathrm{CH}-3003$ Bern, Switzerland, Project 38694, Contract 79385, 2002.

[3] C. Rösch, 'Energetische Nutzung von Biomasse mit Brennstoffzellen', in 'Gülzower Fachgespräche' 1998, 18.

[4] A. Wojcik, P.H. Middleton, I. Damopoulos, J. Van herle, J. Power Sources 2003, $118,342$.

[5] J. Van herle, F. Maréchal, S. Leuenberger, D. Favrat, J. Power Sources 2003, 118, 375.

[6] J. Van herle, F. Maréchal, S. Leuenberger, Y. Membrez, O. Bucheli, D. Favrat, J. Power Sources 2004, 131, 127.

[7] K. Ledjeff-Hey, F. Mahlendorf, J. Roes, 'Brennstoffzellen - Entwicklung, Tech- nologie, Anwendungen', Heidelberg, C.F. Müller-Verlag, 2000.

[8] J.H. Hirschenhofer, D.B. Stauffer, R.R. Englemann, M.G. Klett, 'Fuel Cell Handbook', 4th edition, 1998, DOE/FETC99/1076, United States Department of Energy (DOE), Morgantown WV 265070880 (USA).

[9] E. Newson, T.-B. Truong, Int. J. Hydrogen Energy 2003, 28, 1379.

[10] S. Ahmed, M. Krumpelt, Int. J. Hydrogen Energy 2001, 26, 291.

[11] P. Mizsey, E. Newson, T.-B. Truong, P. Hottinger, Appl. Catal. A: General 2001, 213, 233.

[12] F. Vogel, T.-B. Truong, M. Bosco, E. De Boni, 'Link-up of a 'shift-less' gasoline fuel processor with a polymer electrolyte membrane fuel cell', PSI Scientific Report 2003, Volume V (2004), ISSN 1423-7342, p. $17-18$.

[13] F. Hajbolouri, G.G. Scherer, A. Wokaun, 'Link-up of a gasoline reformer to a polymer electrolyte fuel cell', PSI Scientific Report 2003, Volume V (2004), ISSN 1423-7342, p. 117.

[14] F. Hajbolouri, 'Polymer electrolyte fuel cells: Contributions to the understanding of CO-tolerance', PhD Thesis No. 15525 ETH Zürich, 2004.

[15] G. Robert, E. Batawi, A. Schuler, S. Riggenbach, B. Pietzak, M. Molinelli, J. Van herle, R. Ihringer, O. Bucheli, Chimia 2004, 58, 879. 